\title{
THE INTERPLAY BETWEEN AIR TEMPERATURE AND ICE MASS BALANCE CHANGES IN SCĂRIŞOARA ICE CAVE, ROMANIA
}

\section{POVEZAVA MED TEMPERATURO ZRAKA IN DINAMIKO LEDU V LEDENI JAMI SCĂRIŞOARA, ROMUNIJA}

\author{
Aurel PERȘOIU1 ${ }^{1}$, Bogdan P. ONAC² \& Ioana PERȘOIU ${ }^{3}$
}

\begin{abstract}
UDC 551.444.6:551.525.6(498)
Aurel Perşoiu, Bogdan P. Onac \& Ioana Perşoiu: The interplay between air temperature and ice mass balance changes in Scărişoara Ice Cave, Romania

This paper examines the short-term relations established between external and cave air temperature in Scărişoara Ice Cave (Romania) and the role they play upon ice genesis and mass balance changes. Geothermal heat and external climate are the main drivers of the cave's air temperature, but the ice forming and ablation processes modulate its spatial and temporal characteristics. In the winter half-year, cold air inflow leads to the overcooling of the cave atmosphere and walls and ice formation; while in summer, melting of ice acts as strong thermal sink, keeping the air temperature at $0{ }^{\circ} \mathrm{C}$. In autumn and winter, dynamic cooling of the cave atmosphere leads to ice buildup, whereas in summer, the causality is overturned, the cave air temperature being controlled by the melting ice. The existence of a net heat sink in the cave (melting ice in summer in this case), leads to the overcooling of the non-glaciated parts of the cave as well, a phenomenon that can hamper paleoclimatic reconstructions based on stable isotope studies in speleothems.

Keywords: cave climate, air temperature, ice dynamics, Scărişoara Ice Cave, Romania.
\end{abstract}

\begin{abstract}
Izvleček
UDK 551.444.6:551.525.6(498)

Aurel Perşoiu, Bogdan P. Onac \& Ioana Perşoiu: Povezava med temperaturo zraka in dinamiko ledu v ledeni jami Scărişoara, Romunija
\end{abstract}

Članek obravnava povezavo med zunanjo in jamsko temperaturo zraka ter dinamiko ledu v ledeni jami Scărişoara (Romunija). Geotermična toplota in zunanja klima sta glavna dejavnika temperature zraka v jamah, pomemben vpliv na jamsko klimo pa ima tudi nastajanje in taljenje ledu. Jeseni in pozimi dotok hladnega zraka s površja jamo ohlaja, kar povzroča kopičenje ledu. Poleti je proces obrnjen; taljenje ledu predstavlja toplotni ponor, ki vzdržuje temperaturo jamskega zraka v bližini ledišča. Taljenje torej pomembno vpliva tudi na temperaturo nepoledenelih delov jame, oziroma temperaturo, pri kateri potekajo nekateri procesi (npr. izločanje sige). Slednje lahko bistveno vpliva na pravilnost rekonstrukcije paleoklimatskih parametrov iz kapnikov.

Ključne besede: jamska klima, temperatura zraka, dinamika ledu, ledena jama Scărişoara, Romunija.

\footnotetext{
${ }^{1}$ Department of Geography, "Ştefan cel Mare" University, Universității 13, 720229, Suceava, Romania; Department of Geology, University of South Florida, 4202 E. Fowler Ave. SCA 528, Tampa, 33620, United States, + 40230216147 / 589 , e-mail: aurel.persoiu@gmail.com

${ }^{2}$ Department of Geology, University of South Florida, 4202 E. Fowler Ave. SCA 528, Tampa, 33620, United States; Department of Geology, "Babeş-Bolyai” University, Kogălniceanu 1, 400084, Cluj Napoca, Romania; “Emil Racoviță” Institute of Speleology, Clinicilor 5, Cluj Napoca, 400006, Romania

${ }^{3}$ Department of Geography, "Ştefan cel Mare" University, Universității 13, 720229, Suceava, Romania
}

Received/Prejeto: 28.1.2011 


\section{INTRODUCTION}

The rather stable cave environments have been relatively long recognized to have the potential to preserve past environmental informations in various types of sedimentary archives (speleothemes, fluvial sediments, guano, bones, etc). Recently, it was shown that perennial ice accumulations in caves could also host a wide range of paleoclimatic and paleoenvironmental proxies (Citterio et al. 2004; Holmlund et al. 2005), of which the most important one is the stable isotopic composition of water (i.e., ice). One such promising site is Scărişoara Ice Cave, Romania (Fig. 1, Perşoiu et al. 2011). However, the transfer of the climatic signal recorded by the stable isotope composition of precipitation (a proxy for air temperature, e.g., Dansgaard 1964) to cave drip water and further to ice is not a straightforward process (Yonge \& MacDonald 1999; Kern et al. 2010; May et al. 2010; Perşoiu et al. 2011) given the complex freezing and melting mechanisms involved in ice formation and accumulation (Zelinka 2007; Kadebskaya et al. 2008), and equally complicated relationships between cave and surface climate (Racoviță 1994a; Perşoiu 2004). Specifically, the cave has a complex climatic behavior (Racoviță 1994b), with different parts of it responding differently to external forcing and, moreover, with a strong influence of various ice mass-balance change related processes on cave air temperature. It is thus necessary to disentangle the two and establish a relationship between them, which will further allow us to develop a model of how the cave ice behaved in the past, as a base for paleoclimatic reconstruction.

The aim of this study is to present and explain the interplay between air temperature (both external and cave) and ice dynamics in Scărişoara Ice Cave and its role in the genesis, accumulation, and preservation of the perennial ice block within it.

\section{STUDY SITE}

Scărişoara Ice Cave (700 m long, $105 \mathrm{~m}$ deep) is situated in the Apuseni Mountains (Fig. 1), at 1,165 m above sea level; its entrance opens on the western wall of a circular shaft, $60 \mathrm{~m}$ in diameter and $47 \mathrm{~m}$ deep, the bottom of which is covered by perennial snow (Racoviță \& Onac 2000). Ice in the cave originated from freezing seepage water that accumulated to form one of the largest $\left(>100,000 \mathrm{~km}^{2}\right)$ and oldest (>10,000 years) underground glaciers in the world (Perşoiu, 2011). The ice block forms the floor of the Great Hall, its vertical sides delimiting three distinct sectors of the cave: The Church, Little Reservation, and Great Reservation (Fig. 1). It consists of a sequence of laminated layers, each one containing a couplet of clear ice and impurities (mainly organic matter, calcite, soil, and pollen). Melting and refreezing process at both the top (e.g., Racoviță 1994a) and bottom (Perşoiu \& Pazdur 2011) of the ice block, are reflected in the annual cycle of ice level (and mass) variations, with a maximum in early spring (at the end of the accumulation period) and a minimum in early through late autumn (Racoviță 1994a). These annual cycles are superimposed on longterm variations, influenced by both internal (Şerban et al. 1967; Perşoiu \& Pazdur 2011) and external (i.e., climatic) factors (Racoviță 1994a). Over the past 30 years, the ice block was in a steady state, following a period of rapid and almost continuous melting, in the middle and late $20^{\text {th }}$ century.

The climate of the region is continental temperate. The mean annual temperature near the cave's entrance is $\sim 5.2{ }^{\circ} \mathrm{C}$, the temperature of the coldest month (January) is $-4{ }^{\circ} \mathrm{C}$ (the winter air temperatures varying between $-22{ }^{\circ} \mathrm{C}$ and $+10{ }^{\circ} \mathrm{C}$ ), and of the warmest (July) is $+15{ }^{\circ} \mathrm{C}$ (varying between $+2{ }^{\circ} \mathrm{C}$ and $+30{ }^{\circ} \mathrm{C}$ ), respectively (Orăşeanu \& Varga 2003; this study). The prevailingly western circulation of the air in the Apuseni Mountains causes large precipitation amounts (around 1,200 $\mathrm{mm}$ /year), with the highest values in spring and early summer months and the lowest ones in October.

\section{METHODS}

External air temperature $\left(\mathrm{T}_{\text {air }}\right)$ and precipitation amount were recorded on an hourly basis near the cave's en- trance, between 1 October 2007 and 30 December 2009, using a HOBO Weather Station, with a measurement 


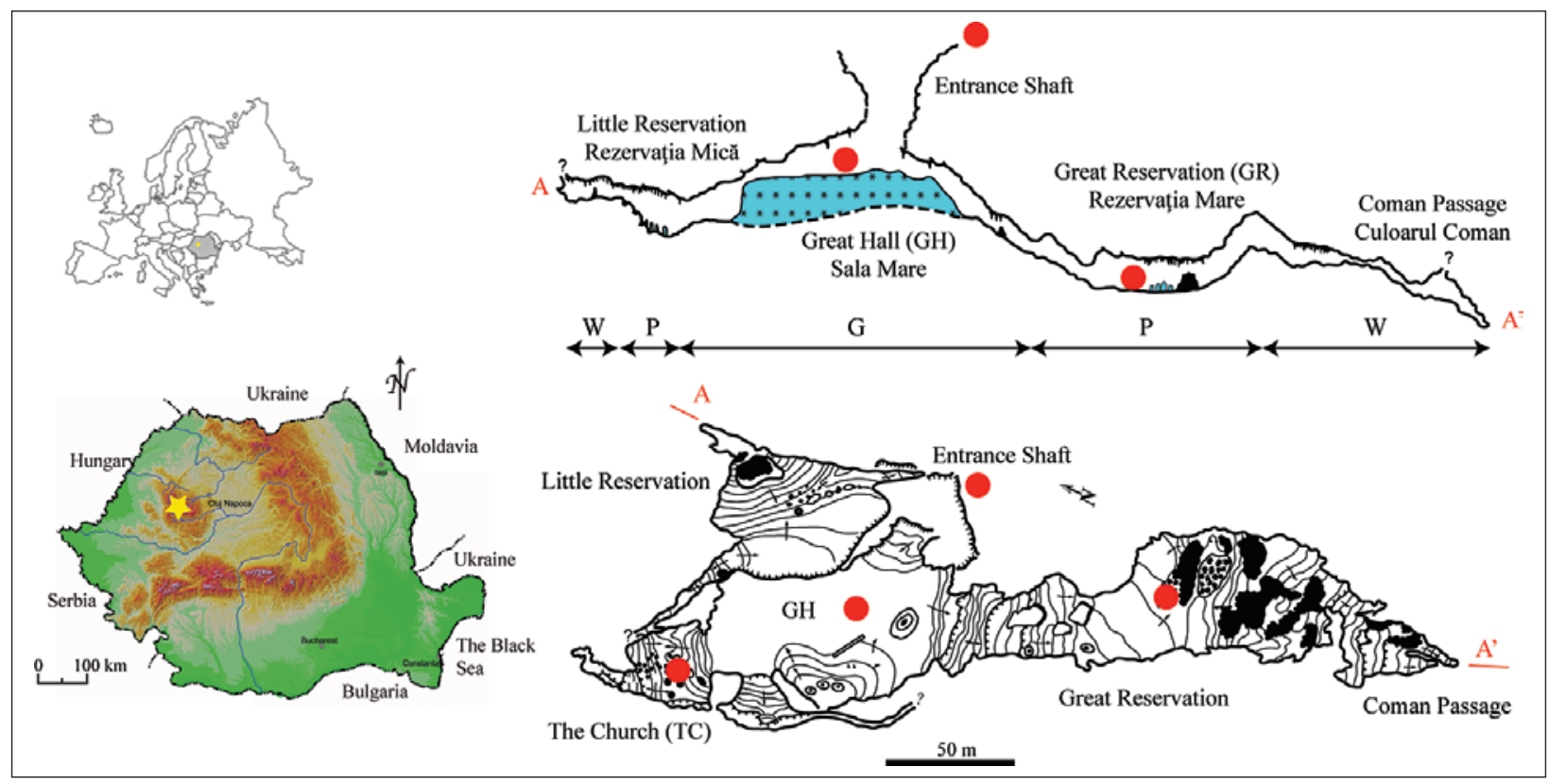

Fig. 1. Location map (the position of the cave is shown by the yellow star), plan view, and cross-section of Scărişoara Ice Cave, Romania (modified from Rusu et al. 1970). On the cross-section, the three climatic zones of the cave (Şerban 1970) are shown: G - glacial, Pperiglacial, $W$-warm.

accuracy of $\pm 0.2^{\circ} \mathrm{C}, 0.02{ }^{\circ} \mathrm{C}$ resolution, and drifts less than $0.1^{\circ} \mathrm{C}$ /year. Rainfall amount has been recorded only when $\mathrm{T}$ was above $0{ }^{\circ} \mathrm{C}$, with a $0.1 \mathrm{~mm}$ resolution.

Cave air temperature was recorded on an hourly basis (over the same period as for the outside meteorological parameters), with Gemini TinyTag Plus dataloggers $\left(0.5^{\circ} \mathrm{C}\right.$ accuracy and $0.01{ }^{\circ} \mathrm{C}$ resolution at $\left.0{ }^{\circ} \mathrm{C}\right)$, in three locations inside the cave (Fig. 1): the Great Hall (GH, $\sim 10 \mathrm{~m}$ from the entrance shaft), the Great Reservation (GR, $210 \mathrm{~m}$ from the entrance) and The Church (TC, $\sim 120 \mathrm{~m}$ from the entrance). The locations have been chosen to reflect the thermal differences existing between the different parts of the cave: the GH is under the direct influence of external meteorological variations, while TC and GR are situated further away from it. Perennial ice is present in the GH and TC (the ice block itself and ice stalagmites and domes), whereas in the GR, the ice has a semi-perennial occurrence, in the form of ice stalagmites and ice crusts. No measurements were performed in the inner sectors of the cave, since Viehmann et al. (1965) and Racoviță (1994b) have shown that the air temperature in these sectors of the cave is constant at $+4.2^{\circ} \mathrm{C}$.

Ice mass balance measurements were carried out on a monthly basis in the $\mathrm{GH}$, by measuring the distance between the ice surface and the overhanging rock wall with a precision of $0.5 \mathrm{~cm}$. In addition, observation on the ice melting and genesis processes were taken approximately every month.

\section{RESULTS AND DISCUSSION}

Figure 2 shows the full record of air temperature changes in Scărişoara Ice Cave compared to the external ones. Three features of the temperature curves are noticeable: 1 ) in phase changes of air temperature in the cave and at the surface, as long as the later are below the cave ones; 2 ) constant $\left(\sim 0^{\circ} \mathrm{C}\right)$ values of air temperature inside the cave when the external ones are above $0{ }^{\circ} \mathrm{C}$; and 3 ) decreasing amplitude of air temperature with increasing dis- tance from the entrance, from $50.7^{\circ} \mathrm{C}$ outside the cave, to $13.9^{\circ} \mathrm{C}$ in $\mathrm{GH}, 8.2{ }^{\circ} \mathrm{C}$ in $\mathrm{TC}$, and $4{ }^{\circ} \mathrm{C}$ in $\mathrm{GR}$.

The maximum air temperatures in the cave never exceed $0.5{ }^{\circ} \mathrm{C}$. The minimum air temperatures follow a similar pattern, decreasing from $-22.5^{\circ} \mathrm{C}$ outside the cave to $-13.8{ }^{\circ} \mathrm{C}$ in the $\mathrm{GH},-8.1{ }^{\circ} \mathrm{C}$ in $\mathrm{TC}$, and $-3.6{ }^{\circ} \mathrm{C}$ in the GR. Thus, the amplitude variations inside the cave are given by the magnitude of air temperature drops be- 


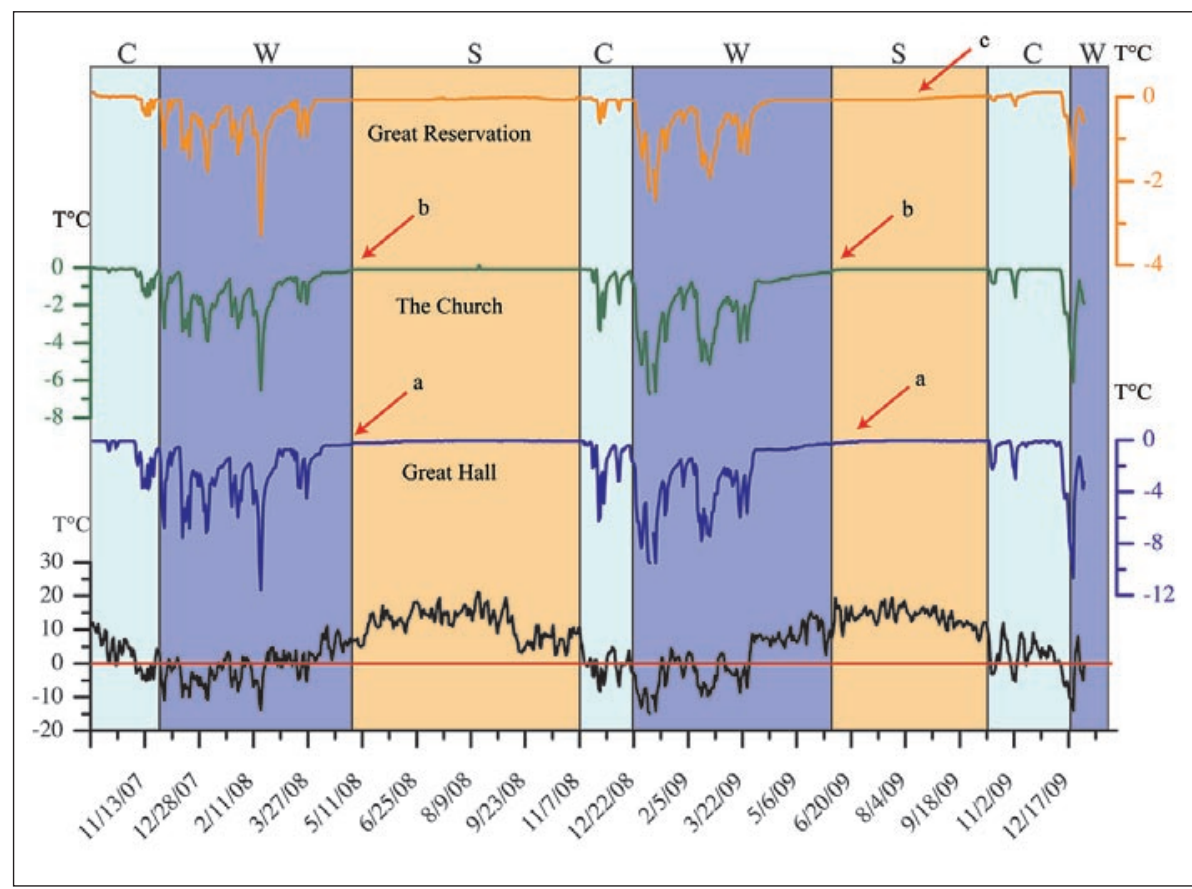

Fig. 2. Time series of daily air temperature in Scărişoara Ice Cave $(C$ - cooling phase, $W$ - winter phase, S-summer phase).

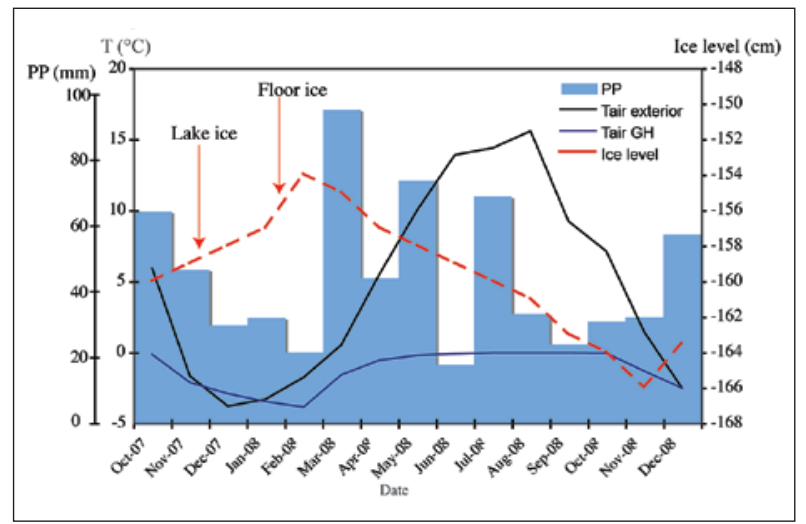

Fig. 3. Monthly values of external air temperature and precipitation, air temperature, and ice level variations in the GH, Scărişoara Ice Cave. No measuremnets of ice level changes were made in December 2007 and February 2008.

low $0{ }^{\circ} \mathrm{C}$. In the inner, non-glaciated parts of the cave (Coman Passage), the air temperature amplitude is $\sim 0.5^{\circ} \mathrm{C}$ (Racoviță 1994a).

Monthly means of air temperature outside the cave and in the GH, precipitation amount, and ice level changes (in the GH, expressed as the distance between the ice surface and the overhanging rock wall) are shown in Fig. 3 (data from October 2007 through December 2008). Precipitation amounts were highly variable, with maximum in March 2008 and (a rather unusual, as generally maximum occurs in late spring through early summer) minimum in June 2008. Ice level changes show a minimum in mid-autumn (November 2008) and maximum in February 2008.

Based on previous work on cave climate (e.g., Racoviță 1994b) and the analysis of our data, we have divided one years' data in three periods, which shall be analyzed separately (Fig. 2). The first one is the summer phase ("S" in Fig. 2) when the cave air temperature rises above $0{ }^{\circ} \mathrm{C}$ and stays constant at this value; the second is the cooling phase ("C" in Fig. 2), between the first inflow of cold air $\left(\mathrm{T}<0{ }^{\circ} \mathrm{C}\right.$, usually in early October) and the complete freezing of the lake water in the GH (late December). The third is the winter phase ("W" in Fig. 2), between the end of the cooling phase and the beginning of summer phase, during which the air temperature is (usually) below $0{ }^{\circ} \mathrm{C}$. The present study relies on the 2007-2008 season data set. Yet, to emphasize (or reject) some of the observations, data from the 2008-2009 season have also been used.

\section{SUMMER PHASE}

It corresponds to the time interval when air temperature in the glaciated part of the cave is maintained at $\sim 0{ }^{\circ} \mathrm{C}$. The onset of this phase is not synchronous in all parts of the cave, occurring ca. 1 month earlier in the GR (2 April 2008) as compared to TC (2 May, "b" arrows in Fig. 2) and the GH (6 May, "a" arrows in Fig. 2).

When the cold air inflow ceases in early spring, air temperature inside the cave begins to rise mostly under the influence of geothermal heat advected from the inner, non-glaciated parts of the cave, and that brought by inflowing warm water; while the conductive heat fluxes through the cave walls in the glaciated parts of the cave are used to thaw the frozen pore waters (Luetscher et al. 2008) and warm the rock, rather than the air.

Racoviță et al. (1991) have shown that the cooling of the walls in the $\mathrm{GH}\left(-4{ }^{\circ} \mathrm{C}\right.$ at $20 \mathrm{~cm}$ depth $)$ and $\mathrm{TC}\left(-2^{\circ} \mathrm{C}\right)$ is stronger than in the $\mathrm{GR}\left(-1^{\circ} \mathrm{C}\right)$, cooling that partly explains the delay in the onset of the summer phase (Fig. 2). The heat stored in the ice also contributes to this delay, the seasonal ice crusts and semiperennial ice stalagmites in the GR having a negligible 

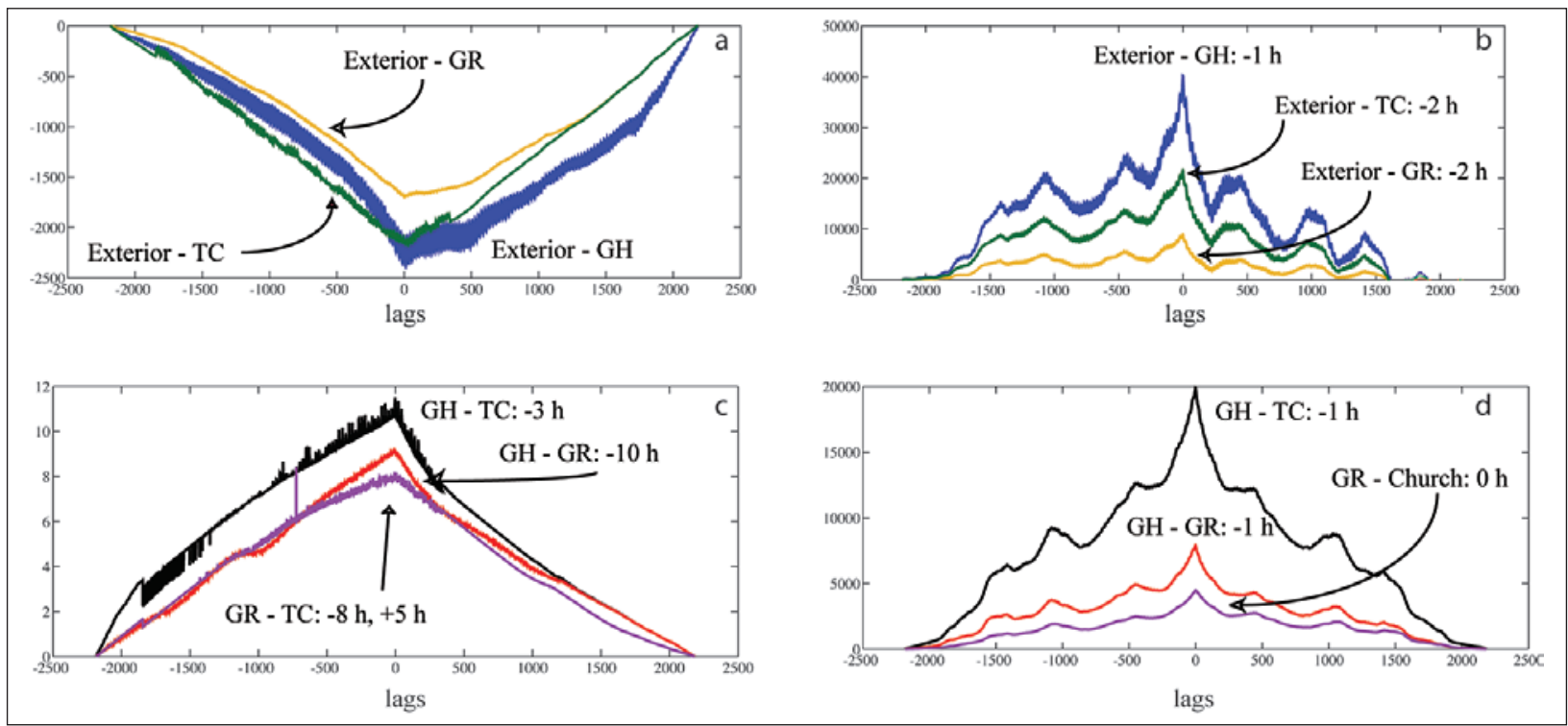

Fig. 4. Cross-correlations of air temperature values (hourly values) between exterior and Scărişoara Ice Cave during (a) summer phase and (b) winter phase; and between different parts of Scărişoara Ice Cave during the summer (c) and winter (d) phases.

thermal inertia as compared to the ice block in the GH and TC.

The onset of the summer phase in the GH and TC is synchronous, although the timing and duration of heat exchanges between the rock walls and ice, on one side, and air temperature, on the other, differ in these two parts of the cave. Strug et al. (2008) have shown that ice temperature changes are synchronous in the GH and TC, so that the sensible heat (and later in the warming processes the latent heat of fusion) stored in the ice affects air temperature in these two rooms in a similar way. However, rock temperature data (unpublished data in the archives of the "Emil Racoviță" Institute of Speleology, Cluj Napoca, Romania) reveal that thawing of the walls occurs ca. 1 month earlier in the GH than in TC (although the cooling is stronger in the former, see above). We suggest that this earlier warming of the walls must be related to the conductive heat transfer through the air column in the entrance shaft next to the GH, which counterbalances the effect of winter cooling. The effect of the heat advected through the entrance shaft on air temperature in the GH (leading to faster warming) must be offset by

Tab. 1. Strength of the $24 \mathrm{~h}$ periodic signal inside and outside Scărişoara Ice Cave.

\begin{tabular}{l|l|l|l}
\hline & $\begin{array}{l}\text { Distance } \\
\text { ( } m \text { from entrance) }\end{array}$ & $\begin{array}{l}\text { Summer } \\
\text { (power in arbitrary units) }\end{array}$ & $\begin{array}{l}\text { Winter } \\
\text { (power in arbitrary units) }\end{array}$ \\
\hline Exterior & - & 18,990 & 8,327 \\
\hline Great Hall & 10 & 0.37 & 147 \\
\hline The Church & 123 & 0 & 23.28 \\
\hline Great Reservation & 200 & 0 & 5.6 \\
\hline
\end{tabular}

the larger area of ice and cold rock in this room than in TC (which leads to a delayed warming), so that the onset of summer phase in these two rooms occurs synchronously.

As soon as air temperature in the cave reaches $0{ }^{\circ} \mathrm{C}$, melting of ice is initiated (Fig. 3), and it is this processes that further controls air temperature. The complete melting of the ice crusts (on the floor and walls) and ice stalagmites in the GR with subsequent drainage of resulting water through the rock fissures, cause a slow increase of air temperature above $0{ }^{\circ} \mathrm{C}$ ("c" arrow in Fig. 2), a process not observed in the TC and GH, where both ice and water are still present.

Spectral analysis reveals no periodic signal in cave air temperature during summer, whereas outside air temperature displays a strong $24 \mathrm{~h}$ periodicity (Tab. 1). Cross-correlograms of external and cave air temperatures show no correlation between the two (Fig. 4a), whereas cross-correlation between the three rooms of the caves show extremely week (Fig. 4c) correlations with random lags (between +5 and $-10 \mathrm{~h}$ ), a clear indication of processes controlled by an external forcing mechanism, which in this case is the melting of ice.

The end of the summer phase occurs with the first inflow of cold air inside the cave usually in mid-October (20 October 2008 and 18 October 2009), but the date is more variable. The timing of the end of the summer phase 


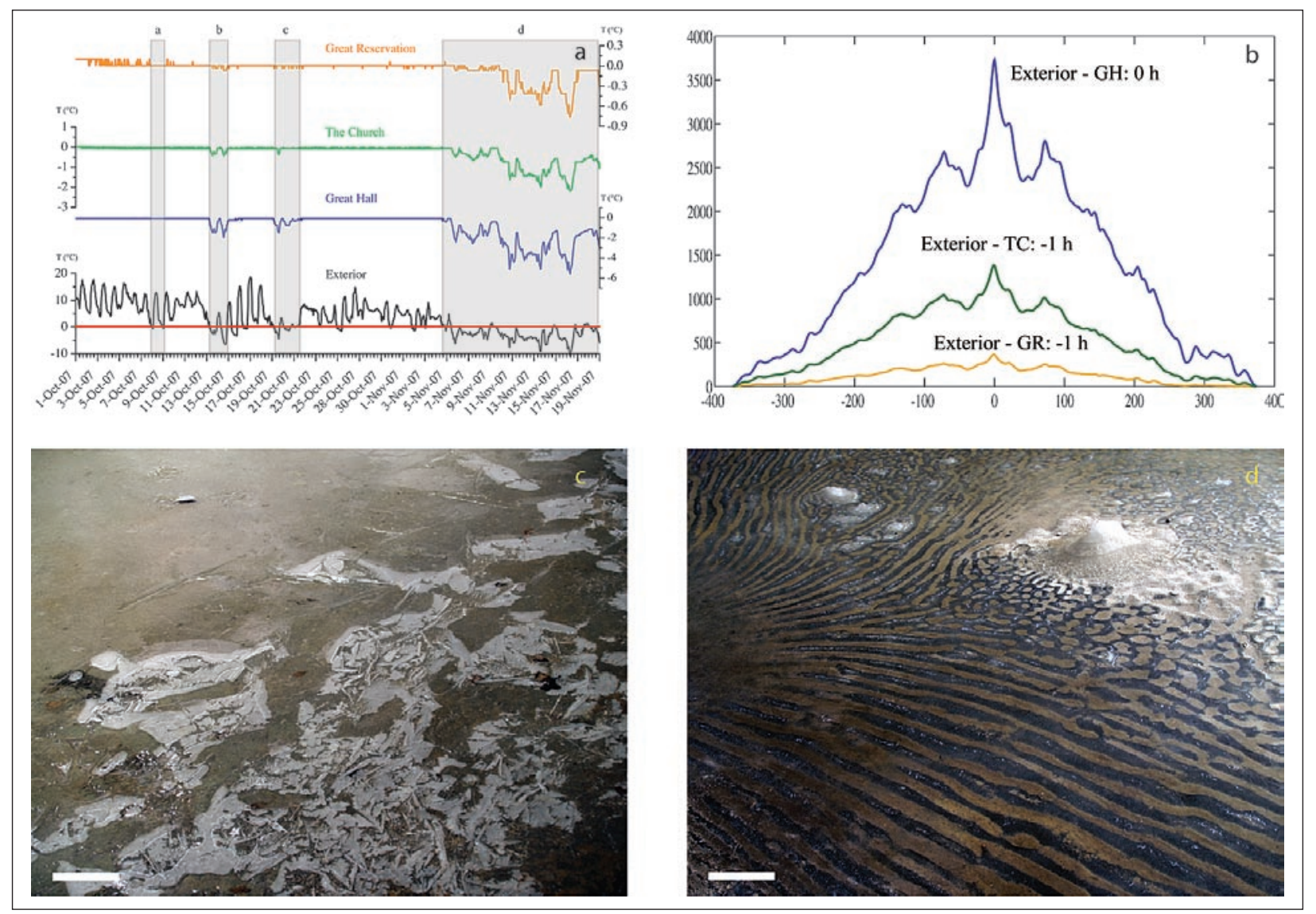

Fig. 5. Cooling phase in Scărişoara Ice Cave: time series of daily air temperature (a), cross-correlation of hourly air temperatures between exterior and the cave (b); ice-crystals formed on top of the lake in the early stage of freezing (c); frozen waves formed during the freezing of lake water (d). The length of the scale bar in (c) and (d) is $8 \mathrm{~cm}$.

between the different parts of the cave depends on two factors - the intensity of the first cooling and its duration, and it will be discussed in more detail in the next chapter.

\section{COOLING PHASE}

Although air temperature drops below $0{ }^{\circ} \mathrm{C}$ (and consequently below cave air temperature) already in early October (Fig. 5a), no changes in air temperature can be noticed inside the cave. However, there must be cold air flow inside the cave due to differences in air temperature and pressure. This cold air will warm due to 1) direct contact with the (still) warm walls, and 2) heat loss towards the evaporating wall moisture; but it will also slightly cool down as the evaporating wall moisture will drawn heat from the air itself (Wigley \& Brown 1976). These evaporation-related temperature changes (Yonge 2004) are of minor importance for the cave's heat balance, as further cooling outside the cave leads to massive cold air avalanches (Perrier et al. 2005) through the entrance shaft, which quickly reach the GH (less than 1 hour, Fig. 5b). This cold air inflow determines the be- ginning of freezing of lake water standing on top of the ice block in the GH. Initially, ice crystals develop at the surface of the water (Fig. 5c) until a continuous ice layer covers the entire lake. Further cooling will determine the complete freezing of the water, from top to bottom, a process that usually takes 1-2 months. Ice mass balance measurements have shown that the level of ice increases by ca. $2-12 \mathrm{~cm}$ during this interval, depending on the depth of the lake before freezing (Fig. 3). Sometimes, the turbulent inflow of cold air (in concert with dripping water) produces small waves on the lake's water, which will be spilled over cold ice and freeze to form a specific pattern (Fig. 5d). In the first stages, the cold wave is not felt deep inside the cave, being warmed as the freezing of water proceeds in the GH. However, continuous and sustained cooling outside the cave (Fig. 5a) leads to a strong cold air advection inside the cave, which will reach the GH and TC (usually with a delay no longer than 1 hour, Fig. 5b). A convective air cell is established, with warm air being replaced and pushed out along the ceiling of the cave. Heating of air in contact with the walls and latent heat transfer from the ice to the air in the process of wa- 
ter freezing increases the air temperature inside the cave and thus the pressure difference between surface and the cave environment, enhancing the speed of inflow air (as also noticed by Pflitsch et al. (2007) in Dobsinšká l'adová jeskiňa, Slovakia, and Ohata et al. (1994) in Fuji Ice Cave, Japan) and leading to further cooling, by a positive feedback mechanism. Cooling outside the cave sends a new wave of cold air inside the cave and the processes is rejuvenated. Once the water inside the cave (lake water in $\mathrm{GH}$ and TC and dripping water in GR) is completely frozen, cooling of the cave air accelerates, as the amount of sensible heat required to cool the ice is smaller than the latent heat required by the freezing process.

Inflow of cold air is intermittent both during the cooling phase, and during the subsequent winter phase (see below). Release of sensible heat (and latent heat as well, during water freezing) slowly warms the undercooled air inside the cave, the air temperature climbing on a ramp-like fashion towards $0{ }^{\circ} \mathrm{C}$ (see Fig. 2). Lowering of external air temperature below the internal one initiates a new pulse of cold air and the cooling resumes.

\section{WINTER PHASE}

The winter phase begins when freezing of lake water (i.e., the standing water on top of the ice block in the GH accumulated during the summer melting phase) completes in early winter (December 5, 2007; December 22, 2008; December 16,2009$)$ and lasts until melting resumes in summer $\left(\mathrm{T}_{\text {air }}>0{ }^{\circ} \mathrm{C}\right.$ : May 2, 2008; June 6, 2009). Although temperature is below $0{ }^{\circ} \mathrm{C}$ a few weeks before the above delimitated start of the cold phase, a lake is still present in the GH (and partly in the TC) and the in-cave processes are still specific for the cooling phase. Once the entire water is frozen, the dominant processes (discussed below) are: 1) turbulent inflow of cold air towards the GH, TC, and GR, 2) sensible heat transfer from rock and ice to air, accompanied by a slow warming of air, and 3) strengthening of warm air outflow (from the inner, non-glaciated part of the cave) along the cave's ceiling and subsequent condensation of water. The cold airwave reaches the GH with a delay of about $1 \mathrm{~h}$ (Fig. $4 \mathrm{~b}$ ), which increases to $2 \mathrm{~h}$ in the GR and TC. Moreover, there is a similar $1 \mathrm{~h}$ lag between air temperature changes in the $\mathrm{GH}$, on one side, and the GR and TC on the other side (Fig. 4d), indicating that the inflowing cold air, divided into to branches, reach the inner parts of the cave in about the same time $(0 \mathrm{~h}$ lag between the GR and TC). The curves in Figs. $4 \mathrm{~b}$ and $4 \mathrm{~d}$ are based on data from the entire winter phase, thus taking into consideration also periods when the temperature outside the cave is equal or slightly above that inside the cave (e.g., between January 23 and 29, 2009, Fig. 2), when no inflow of cold air is noticeable. If we consider only the period when $\mathrm{T}_{\text {air }}$ outside the cave is below $\mathrm{T}_{\text {air }}$ inside (e.g., February 9-27, 2009), the lag between the $\mathrm{T}_{\text {air }}$ outside and inside the cave is less than $1 \mathrm{~h}$, emphasizing the quick transfer of surface cold air into the cave. The good correlation between the two environments is evident if we consider the strength of the $24 \mathrm{~h}$ periodic signal, which is stronger than in summer (Tab. 1), and diminishes with increased distance from the entrance.

Negative temperatures never penetrate at depths greater than $150 \mathrm{~cm}$ (Strug et al. 2008) in ice, while in rock they exceed $20 \mathrm{~cm}$ (the maximum depth reached by winter cooling is not known, but studies elsewhere (Luetscher et al. 2008) have shown that it could be as deep as $80 \mathrm{~cm}$ ). In winter, dripping condensation water (Racoviță \& Viehmann 1984) and occasional inflow from liquid precipitation freezes in the undercooled environment to form floor ice (Fig. 3; thin layers - up to 1-2 cm each - of ice on top of the autumn lake ice) and ice stalagmites in the GH, TC, and GR. The processes are especially active in early winter, when the air temperature near the cave ceiling is still positive and water droplets rather than hoar frost form through condensation (as opposed to later in the winter). Similar types of ice form during warm and wet periods, when precipitation water is reaching the undercooled cave environment. A second, more important period of floor ice and ice stalagmite formation is in early to late spring, when melting of snow and spring rains enhance dripping (Racoviță \& Crăciun 1970). However, the heat advected by the dripping water, combined with the prolonged absence of cold air inflow (Fig. 2), rapidly overcome the heat absorbing capacity of the ice and rapid melting of the formations begins (Fig. 3).

\section{A CONCEPTUAL MODEL OF HEAT RESERVOIRS, SINKS, AND FLUXES IN SCĂRIŞOARA ICE CAVE. IMPLICATIONS FOR PALEOCLIMATIC STUDIES}

In non-glaciated caves, the thermal balance of the cave's air is controlled mainly (Racoviță 1994b; Luetscher \& Jeannin 2004) by the heat fluxes conducted through the rock walls (both external and geothermal heat) and those advected through the cave entrance(s) (the case of caves with flowing water is not considered here). Heat 


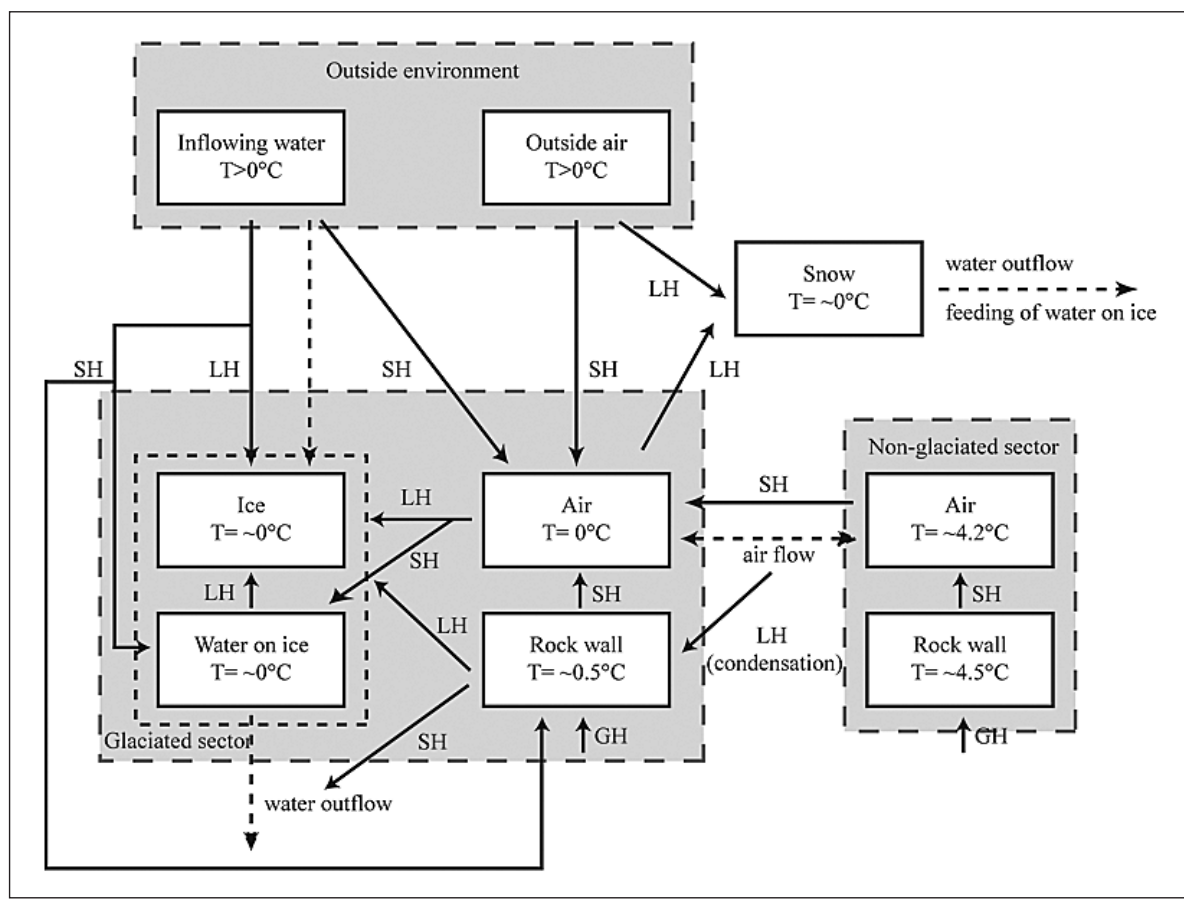

Fig. 6. Conceptual model of the heat and matter fluxes between the different parts of Scărişoara Ice Cave in the summer state (full arrows - heat fluxes, dashed arrow - matter flux, SH - sensible heat, $L H$ - latent heat, GH - geothermal heat).

absorbed and released during the water phase changes plays a minor role (Luetscher, 2005). This rather simple picture is far more complicated within ice caves by the

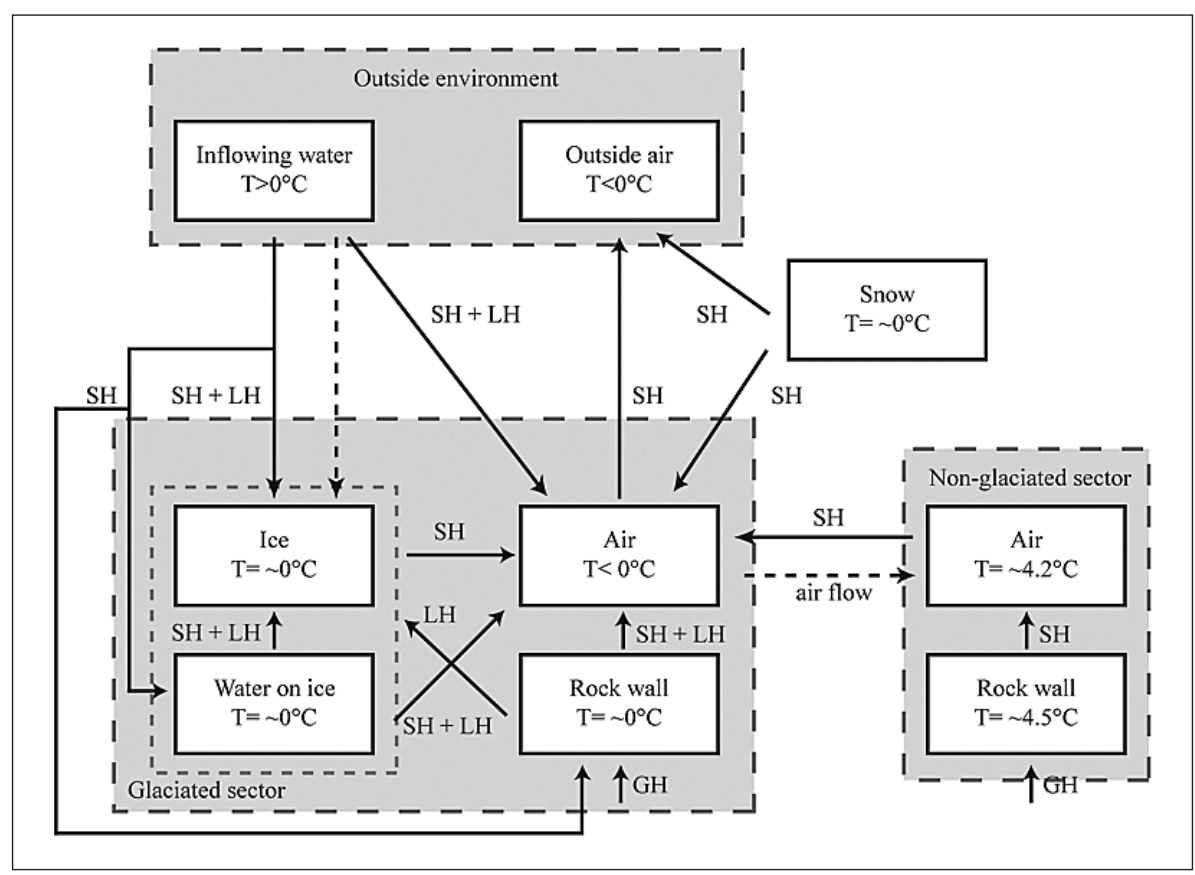

Fig. 7. Conceptual model of the heat and matter fluxes between the different parts of Scărişoara Ice Cave in the cooling state (legend similar to Fig. 6). presence of ice and its phase changes with the associated heat (and matter) fluxes (Figs. 6-9). Depending on the air temperature variations outside, three main states can be recognized in the organization of the heat fluxes in Scărişoara Ice Cave: summer, cooling, and winter state.

In the summer state, all heat fluxes are directed towards the ice block and the air in the glaciated part of the cave (Fig. 6). The inner, nonglaciated part of the cave and the warm outside air act as heat sources, while the melting ice (and snow at the bottom of the entrance shaft) is a strong heat sink, thus keeping the air temperature in the glaciated part of the cave at $0{ }^{\circ} \mathrm{C}$ (Fig. 2). The sensible and latent heat absorbed by the melting ice is carried away by outflowing water. A side, but notable effect of the strong heat fluxes towards the melting ice block is the lowering of the mean annual air temperature (MAT) in the non-glaciated sector of the cave by $\sim{ }^{\circ} \mathrm{C}$ below the external MAT. MAT in caves in the temperate climatic belt approximates the MAT outside the cave (Wigley \& Brown 1976; Badino 2010), and this lowering could have an important impact on paleoclimatic reconstructions using the $\delta^{18} \mathrm{O}$ of speleothemes as proxy for air temperature (McDermott 2004; Lachniet 2009).

The cooling state is a transitional one, the major role in the dynamics of the heat fluxes being the inflow of cold air, which acts as a heat sink (Fig. 7). The heat fluxes between the ice (and snow) and air reverse, leading to cave cooling and the freezing of water and genesis of ice. The latent heat of freezing in 


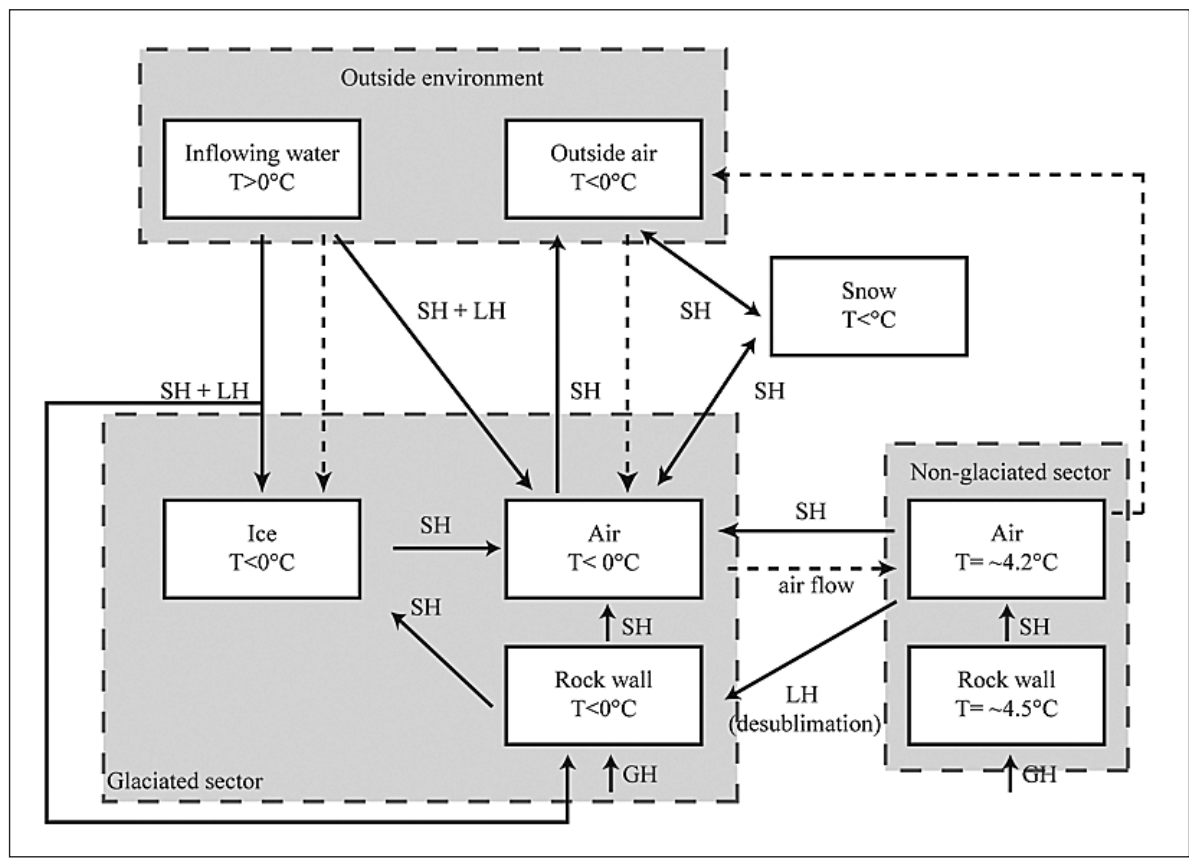

Fig. 8. Conceptual model of the heat and matter fluxes between the different parts of Scărişoara Ice Cave in the winter state (legend similar to Fig. 6).

the lake water and the sensible heat from the inner parts of the cave are the main sources of heat in this state, with the later acting continuously, and the former only for ca. 1-2 months, depending on the strength and temperature of inflowing cold air.

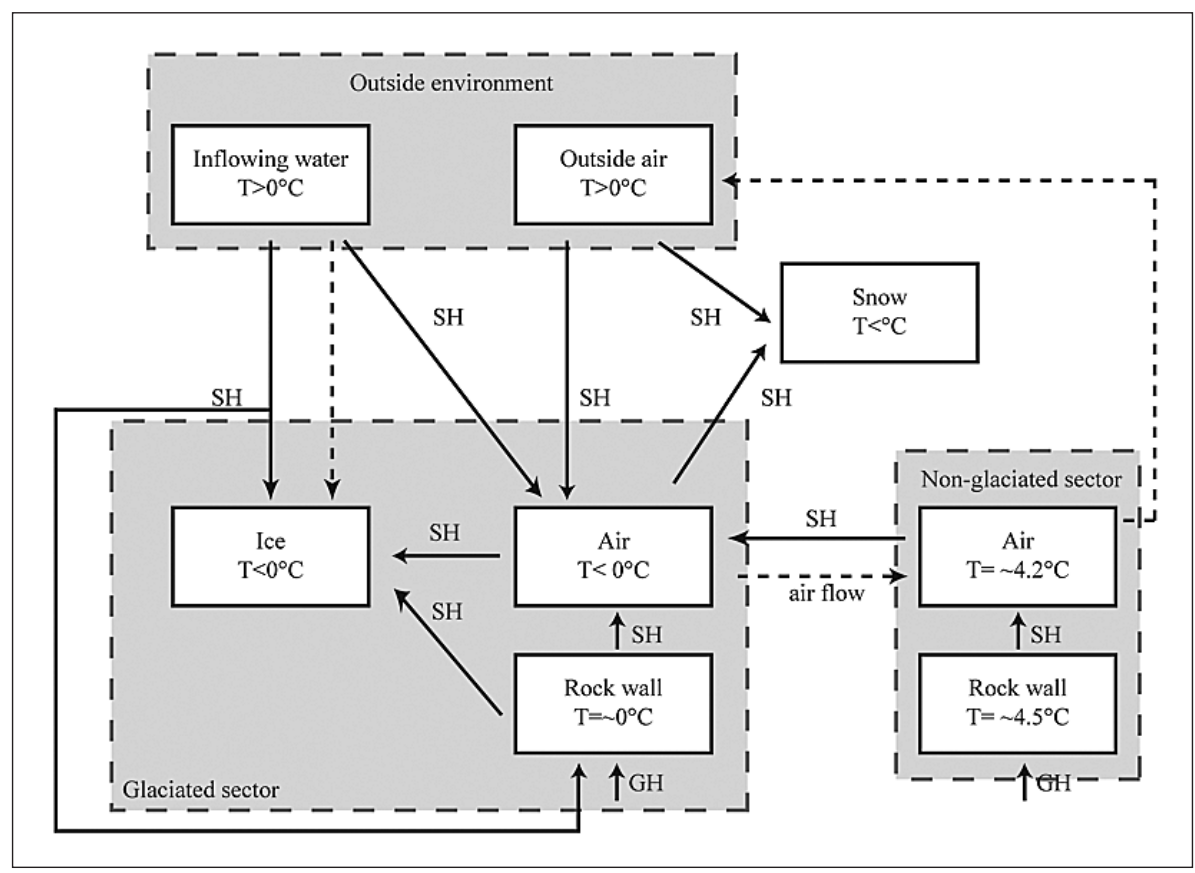

Fig. 9. Conceptual model of the heat and matter fluxes between the different parts of Scărişoara Ice Cave at the end of winter state (legend similar to Fig. 6).
Once the water inside the cave is frozen (except for any occasional inflow), the winter state (a simplified version of the cooling phase) establishes inside the cave (Fig. 8). The heat advected from the inner parts of the cave and the rock walls is consumed in warming the down flowing cold air, which in this case is the main heat sink.

In all three states above, supplemental heat originates from inflowing water, and is generally quickly absorbed by the cold air and the ice, ultimately leading to floor ice (Fig. 3) and ice stalagmites formation (and, once the under cooling of the rock walls reaches the ceiling of the cave, ice stalactites).

However, during winter state, if external air temperatures are above internal ones, the heat fluxes quickly reverse, being directed towards the cave air and ice, slightly warming both of them (Fig. 9). External cooling and inflow of cold air, once again reverses the heat fluxes back to the situation described in Fig. 8. At the end of the winter, heat originating in the external warm air (Fig. 2) and increased inflow of water (Fig. 3) causes another reversal of heat fluxes, which are now directed towards both air and also the ice formations. Heat (both sensible and latent) is rapidly absorbed by the (initially warming and later melting) ice, keeping air temperature close to $0{ }^{\circ} \mathrm{C}$ (Fig. 9).

Additional source of heat is that supplied by the touristic use of the cave, i.e., the lightning equipment (incandescent lamps) and the tourists themselves. Whereas the heat generated by the lamps is low $(\sim 45 \mathrm{~W} / \mathrm{h})$, that originating form the meta- 


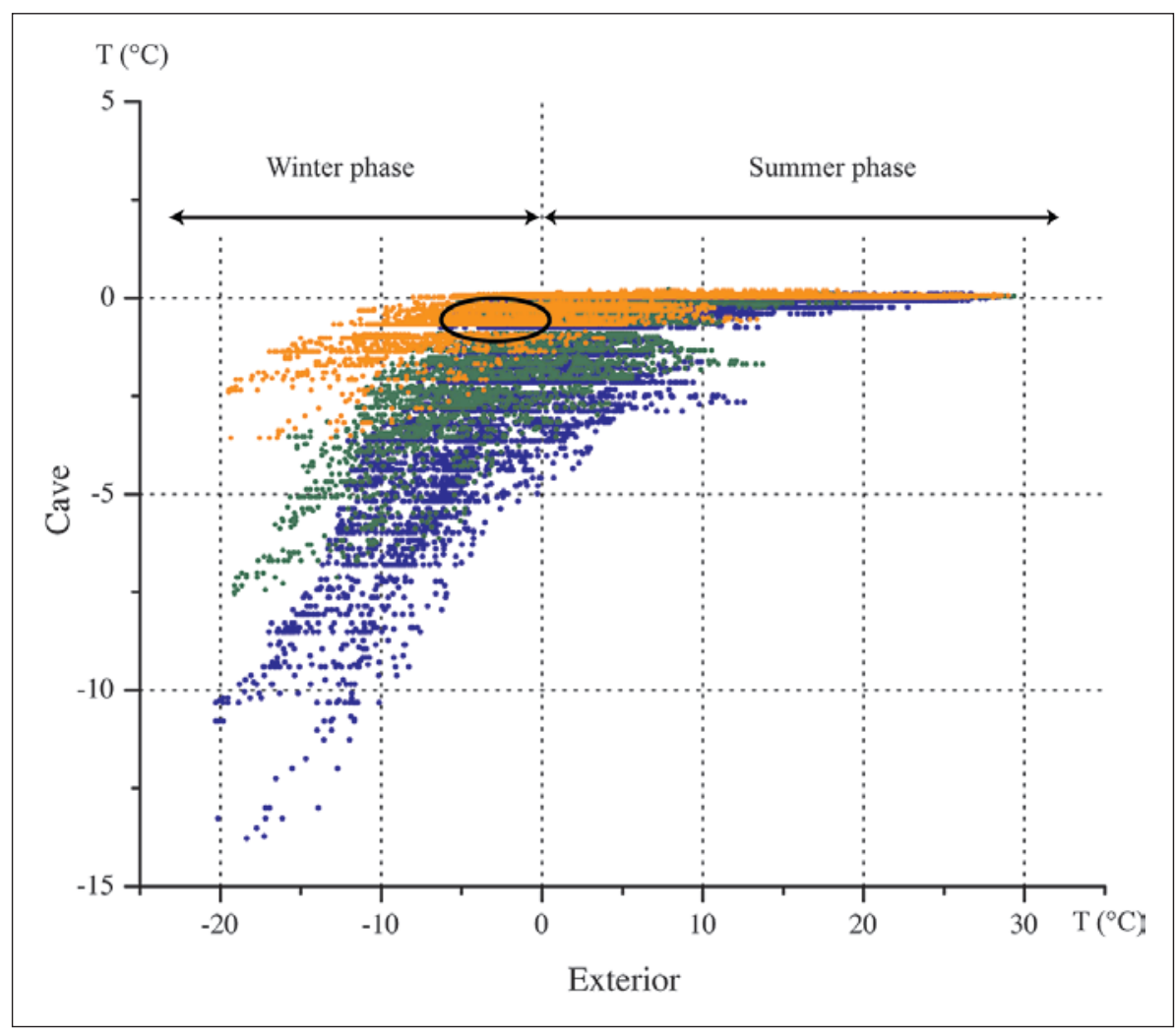

Fig. 10. Summary of air temperature variations in Scărişoara Ice Cave. The black ellipse shows the air temperature range when most of the ice forms (including the cooling period, but not limited to it). bolic heat production (e.g., Yamane et al. 2010) is more important $\left(>350 \mathrm{~W} / \mathrm{m}^{2} / \mathrm{h}\right.$, Osczevski, 1995). Occasional measurements near the tourist path in Scărişoara Ice Cave have shown that the air temperature rises by ca. $3{ }^{\circ} \mathrm{C}$ immediately after a tourists group (usually 40-70 persons) passed the sensor, but it drops to $0{ }^{\circ} \mathrm{C}$ in less than $1 \mathrm{~h}$. However, during heavy use of the cave (summer week ends and holidays), visitors are constantly present inside the cave and the air temperature remains at positive values in the close vicinity of the tourist path. However, no temperature rise was recorded by any of the data logger placed $\sim 10 \mathrm{~m}$ away from the tourist path. Thus, we conclude that heat quickly dissipates without a noticeable effect on ice mass balance changes and/or air warming

\section{CONCLUSIONS}

Air fluxes in Scărişoara Ice Cave act as heat sinks (both sensible and latent) lowering the cave mean annual air temperature below the external one. The processes related to ice mass balance changes, namely melting and freezing of water, are redistributing the heat throughout the year. The main periods of ice formation are in late autumn, when cold air avalanches lead to the freezing of water pooling on top of the ice block and in winter through spring, when inflowing water freezes on top of the previously formed ice. Following the complete freezing of the water, further cooling of the cave atmosphere is initiated, the cold wave propagating towards the inner, non-glaciated sectors of the cave. However, sensible heat release from the cave walls prevent under-cooling in the deeper parts of the cave, where air temperature remains above $0{ }^{\circ} \mathrm{C}$, but still below the mean annual air temperature outside the cave. From mid-autumn until late spring, a strong coupling exists between surface and cave air temperature changes, with cold spells instantaneously transmitted inside the cave (less than $1 \mathrm{~h}$ ), whilst the heat released by freezing water delays the long-term cooling by ca. 2 months (Fig. 3). Warming of the cave air occurs in mid-spring, mostly as a consequence of heat delivered to the cave atmosphere by melting snow and enhanced precipitation, as well as cessation of heat sinking in the inflowing cold air. In summer, the external and cave environment are not connected via a dynamic process (i.e., air mass transfer). Conductive transfer through the air column in the entrance shaft and the rock walls, and through dripping water are the main sources of heat for the cave. Latent heat consumed in thawing of ice in the rock walls pores, sensible heat transferred to the warming ice and rock, and latent heat uptake by melting ice, are the main heat sinks that maintain the air temperature at $0{ }^{\circ} \mathrm{C}$. The last process is responsible for the preservation of the ice block, as its large surface $\left(>3000 \mathrm{~m}^{2}\right)$ absorbs considerable amounts of heat and limits melting to a few $\mathrm{cm} /$ year on a vertical scale, melting that is overcompensated by the winter accumulation. The surface area of ice subject to melting seems to play an important role in the 
preservations of ice, as cave ice bodies with a small surface have a larger year-to-year level variations (e.g., up to a few meters/year in Svarthamarhola Cave; Lauritzen 2010, pers. comm.).
Our (and previous) data suggest that the ice block in Scărişoara Ice Cave has a complex response to external (short and long-term) climate variations, thus, its future behavior under changing climatic conditions is more difficult to predict compared to surface glaciers.

\section{ACKNOWLEDGMENTS}

This study is based on work supported by a Cave Conservancy Foundation fellowship to AP and a NSF grant (AGS-0823253) to BPO. The Apuseni Natural Park Administration is thanked for granting approval for field- work and cave monitoring over the period of this study. Paşca Nicodim kindly agreed to maintain functional the HOBO Weather Station and help with ice level measurements.

\section{REFERENCES}

Badino, G., 2010: Underground meteorology - "What's the weather underground?".- Acta Carsologica, 39, 3, 427-448.

Citterio, M., Turri, S., Bini, A., Maggi, V., Pelfini, M., Pini, R., Ravazzi, C., Santilli, M., Stenni, B. \& R. Udisti, 2004: Multidisciplinary approach to the study of the Lo Lc 1650 "Abisso sul Margine dell'Alto Bregai" ice cave (Lecco, Italy).- Theoretical and Applied Karstology, 17, 27-44.

Dansgaard, W., 1964: Stable isotopes in precipitation.Tellus, 16, 436-468.

Feurdean, A., Perşoiu A., Pazdur A. \& B.P. Onac, 2011: Evaluating the palaeoecological potential of pollen recovered from ice in caves: a case study from Scărişoara, Romania.- Review of Palaeobotany and Palynology, 165, 1-10.

Holmlund, P., Onac, B.P., Hansson, M., Holmgren, K., Morth, M., Nyman, N. \& A. Perşoiu, 2005: Assessing the palaeoclimate potential of cave glaciers: the example of the Scărişoara Ice Cave (Romania).Geografiska Annaller, Series A, 87, 193-201.

Kadebskaya, O., Mavlyudov, B.R. \& M. Pyatunin (eds.), 2008: Proceedings of the $3^{\text {rd }}$ International Workshop on Ice Caves.- Mining Institute of Ural Branch of the Russian Academy of Sciences, pp. 122, Perm.

Kern, Z., Fórizs, I., Molnár, M., Nagy, B. \& R. Pavuza, 2010: Isotope hydrological studies on the perennial ice deposit of Saarhalle, Mammuthöhle, Dachstein Mts., Austria.- The Cryosphere Discussiosn, 4, 1449-1465.
Lachniet, M.S., 2009: Climatic and environmental controls on speleothem oxygen-isotope values.- Quaternary Science Reviews, 28, 412-432.

Luetscher, M., 2005: Processes in ice caves and their significance for paleoenvironmental reconstructions. Swiss Institute for Speleology and Karst Studies, pp. 154, La Chaux-de-Fonds, Switzerland.

Luetscher, M. \& Jeannin, P.-Y., 2004: Temperature distribution in karst systems: the role of air and water fluxes.- Terra Nova, 16, 344-350.

Luetscher, M., Lismonde, B. \& P.-Y. Jeannin, 2008: Heat exchanges in the heterothermic zone of a karst system: Monlesi cave, Swiss Jura Mountains.- Journal of Geophysical Research, 113, F02025, doi: 10.1029/2007JF000892.

May, B., Spötl, C., Wagenbach, D., Dublyansky, Y. \& J. Liebl, 2010: First investigations of an ice core from Eisriesenwelt cave (Austria).- The Cryosphere Discussiosn, 4, 1525-1559.

McDermott, F., 2004: Palaeo-climate reconstruction from stable isotope variations in speleothems: a review.- Quaternary Science Reviews, 23, 901-918.

Ohata, T., Furukawa, T. \& K. Higuchi, 1994: Glacioclimatological study of perennial ice in the Fuji Ice cave, Japan. Part 1. Seasonal variation and mechanism of maintenance.- Arctic and Alpine Research, $26,3,227-237$.

Osczevski, R.J., 1995: The basis of wind chill.- Arctic, 48, 372-382. 
Orăşeanu, I. \& I. Varga, 2003: Meteorological data in the Ghețar area (com. Gârda de Sus, jud. Alba) ( $1^{\text {st }}$ part).- Nymphaea, 30, 3-24 (in Romanian).

Perrier, F., Le Mouel, J.L., Kossobokov, V., Crouzeix, C., Morat, P. \& P. Richon, 2005: Properties of turbulent air avalanches in a vertical pit.- European Physical Journal B, 46, 4, 563-579.

Perşoiu, A., 2004: Ice speleothemes in Scărişoara Cave: dynamics and controllers.- Theoretical and Applied Karstology, 17, 71-76.

Perşoiu, A., 2011: Palaeoclimatic significance of perennial ice accumulations in caves: an example from Scărişoara Ice Cave, Romania. Unpublished PhD thesis, University of South Florida, Tampa, USA.

Perşoiu, A. \& A. Pazdur, 2011: Ice genesis and its longterm dynamics in Scărişoara Ice Cave, Romania.The Cryosphere, 5, 45-53.

Perşoiu, A., Bojar, A.-V. \& B.P. Onac, 2007: Stable isotopes in cave ice: what do they tell us?- Studia UBB Geologia, 52, 1, 59-62.

Perşoiu, A., Onac, B.P., Wynn, J., Bojar, A.-V. \& K. Holmgren, 2011: Stable isotopes behavior during cave ice formation by water freezing in Scărişoara Ice Cave, instead of cave. Romania.- Journal of Geophysical Research, Atmosphere, 116, D02111, doi: 10.1029/2010JD014477.

Pflitsch, A., Piasecki, J., Sawiński, T., Strug, K. \& J. Zelinka, 2007: Development and degradation of ice crystals sediment in the Dobšinska Ice Cave (Slovakia).- In: Zelinka, J. (ed.) Proceedings of the $2^{\text {nd }}$ International Workshop on Ice Caves. Slovak Caves Administration, pp. 38-49, Liptovský Mikuláš.

Racoviță, G., 1994a: Elements fondamentaux dans la dynamique des spéléothèmes de glace de la grotte de Scărişoara, en relation avec la météorologie externe.- Theorethical and Applied Karstology, 7, 133-148.

Racoviță, G., 1994b: Bilan climatique de la grotte glacière de Scărişoara, dressé sur dix années d’observations.Travaux de l'Institute de Spéologie "Emil Racovitza”, 33, 107-158.

Racoviță, G. \& V. Crăciun, 1970: Considérations sur la variation saisonnèire des formations de glace de la grotte "Ghețarul de la Scărişoara”.- Livre du centenaire "Emile G. Racoviță" 1868-1968, 587-616.

Racoviță, G. \& Onac, B.P., 2000: Scărişoara Glacier Cave. Monographic Study.- Editura Carpatica, pp. 140, Cluj-Napoca.
Racoviță, G., Boghean, V., Silvestru, E. \& M. Petrescu, 1991: Etude thermométrique des substratums de la Grotte de Scărişoara.- Travaux de l'Institute de Spéologie "Emil Racovitza”, 30, 159-184.

Rusu, T., Racoviță, G. \& D. Coman, 1970: Contribution a l'étude du complexe karstique de Scărişoara.- Annales de Speleologie, 25, 383-408.

Strug, K., Perşoiu, A. \& J. Zelinka, 2008: Preliminary results of ice temperature measurements in the Dobšinská Ice Cave (Slovakia) and Scărişoara Ice Cave (Romania).- In: Kadebskaya, O., Mavlyudov, B.R., \& M. Pyatunin (eds.) Proceedings of the $3^{\text {rd }}$ International Workshop on Ice Caves. Mining Institute of Ural Branch of the Russian Academy of Sciences, pp. 16-22, Perm.

Şerban, M., 1970: Morphologie comparée des stalagmites de glace de la grotte de Scărişoara (Roumanie).Travaux de l'Institute de Spéologie "Emil Racovitza", 9, 35-60.

Şerban, M., Blaga, L., Blaga, L., Chifu, A. \& T. Ciobotaru, 1967: Contribuții la stratigrafia depozitelor de gheață din "Ghețarul de la Scărişoara”.- Lucrările Institutului de Speologie "Emil Racoviță", 6, 107-140.

Viehmann, I., Racoviță, G. \& M. Şerban, 1965: Observații asupra microclimei Ghețarului de la Scărişoara.Lucrările Institutului de Speologie "Emil Racoviță", 4, 104-115.

Wigley, T.M.L. \& M.C. Brown, 1976: The Physics of Caves.- In: Ford, T.D. \& C.H.D. Cullingford (eds.) The Science of Speleology, Elsevier, pp. 329-358, New York.

Yamane, M., Oida, Y., Ohnishi, N., Matsumoto, T. \& K. Kitagawa, 2010: Effects of wind and rain on thermal responses of humans in a mildly cold environment.- European Journal of Applied Physiology $109,117-123$.

Yonge, C.J., 2004: Ice in caves.- In: White, W.B. \& D.C. Culver (eds.) Encyclopedia of Caves. Elsevier Academic press, pp. 435-437, Amsterdam, Boston.

Yonge, C.J. \& W.D. MacDonald, 1999: The potential of perennial cave ice in isotope palaeoclimatology.Boreas, 28, 357-362.

Zelinka, J. (ed.), 2007: Proceedings of the $2^{\text {nd }}$ International Workshop on Ice Caves.- Slovak Caves Administration, pp. 105, Liptovský Mikuláš. 